\title{
シンポジアムの 部
}

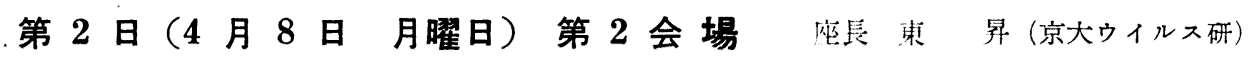

\section{i 微生物の核の諸問題}

湯 浅 明 (東大教養生物)

演者は細胞学者であるので, 植物細胞としてみたバク テリアについて語り, また, 主として光学顕微鏡による 観察をもととして発言をすすめたいと思う。

1936 年に演者が 細菌類の核の問題を 綜説したときに は,バクテリアの核についてはつぎのように考えられて いた。1）バクテリアは核をもたない，2）バクテリア は裸の核である，3）分散核をもつ，4）いろいろな形 の核をもつ，5）一つあるいは二つ以上の真の核をも つ，6）遗伝子をもつ gene-stringをもつている。

しかし，その後，Feulgen 反忘が生物の核を証明する 良好な方法であることが知られて，乙れを利用して，バ クテリアの核を見出そうとする試及が多く抬てなわれ た。しかし, Feulgenの反応については, Stille (1937), Knaysi (1944, 1945, 1946), DeLamater (1953)など の研究によつて, 核検出の適否が論じられたが, 高等生 物に怙ける, この反応の妥当性から反て, バクテリアに ついてもとの反応の正しさは認めてょいょうに思う。

この方法によると Mycobacterium 607 では, 各細胞 に一つづつの核がみられるが, この他, 液胞, 小形のコ ンドリオゾーム，乙れと性質の類似する大形コンドリオ ゾームなどがみられる。核分裂は無系分裂であるが, 紡 鏵体様のものがみられ, 将来, 核の内容すなわちラセン 系と紡錘体とがみられる可能性がある。

バクテリアの従来知られた核分裂から，そ心核分裂の 進化の方式が考えられる。な挍，鞭毛の基部にある生毛 体は, 単細胞植物や精子の生毛体に匹敵し, 核起元と考 えれらる。

1) Feulgen 反応の検討，2）1細胞中の核の数, 3）核と大形コンドリオゾームとの区別，4）核の内部 構造，5）核膜について，6）核分裂の紡錘体，7） ラ セン系の検出などは, 将来の問題である。

Bac. megatherium については, 核をみとめたが, こ れは大形の高等生物の核に匹数するものであり，その両 側に，核分裂の際に紡鍾体をみとめうるが，紡鍾体の中 には中心粒が埋在している。DeLamater (1951 以降) の研究と演者の考えとの差異を述べる。

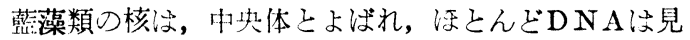
られないが, この中心ラセン模造の存在がみられ, 進化 の途中にある核，京るい煺化の途中にある核と考えら れる。

従来, 生物の中で, 無核と考えられた三つのものは, バクテリア, 藍藻類, コウボキンであつたが, その中, バクテリア上蔡藻類とは, 未ず有核と考えられるょうこ なり，コウボギンの放開の中にのとされている。この 核については, 正常核を考えた人, 液胞核を考える人, 特殊核を考学る人とがあり，核分裂についても議論粉心 である。これらの閣題について論述与る。
追 加
落沼 惊 (京都有医微生物)

私共の写蒖で大腸菌の表面に見られる落及が Nuclearsite と考えることについての御意胃を扮同いしたい。

回 答

湯 浅 明（東大教養生物，

核とは考えられるょうです。高等植物では強度や固定 液などの影響で，核上細胞質との間に Hof ができて, 核自身が収縮して，「洼及になるのではあり李せんか？

回 答 座長

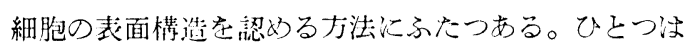
シヤドウイング法, 他はレプリカ法である。菅沼氏が後

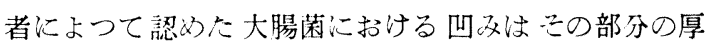
み, 密度抢上で原子番号特们厚みが他の部分より小さい ためである。

\section{附 諲吉井 善作 (山口医大, 微生物)}

各種の細菌の鞭毛根部には顆粒が㴓められたとの報告 はかなりあり，久，私も二，三の細菌で認めて施り忘 す。先程との鞭毛颗粒在生毛体と呼び, 中心体との関斬 につを若干触れられ梞したが，もら少し辣しく御考えを おきか+願いたい。

\section{回答湯 浅 吸 (東大教養生物)}

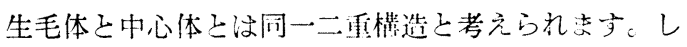
かも, この起元は核の中らしいと思われる。バクテリア の生毛体も, その起元は核であり, Feulgen 陽性の場 合が多いと思われき立。

\section{附㦈渡辺力(慶応細荡)}

核について, 細萂の增殖の各時期, 各菌種により兰の 
数の変化を迫求された研究があれ茜打うが゙いしたい。

回答湯浅明 (東大教垠生物)

バクテリアさ一紐胞一核が原則であり，宗な核の中に

は Chromonema が見られるようになり，原則的にはバ クテリアの核も高等生物のもの上变らない上思われま 守。バクテリアの sex, 㑕命, 減数分数などのとともや がて闭かになると思い染す。

\section{附 㦈渡辺守松 (家畜衛試)}

加水分解をしないてもギムザ染色在澧くしてからアセ トンアルコールで分別すれば核洨奇歾に染出されます。

\section{罂 問 \\ 渡边 守松(家畜衛試)}

キムザ染色で 核の位置に相当して Density の高い顆 粒犬゙炭疽菌で見られる。核であるかどうかわからない ふ，一般核㤝 Density が低いといわ礼ているので， 椇上考えると反刘になる。但し私共の槽本では Osmic acid で固定していないので，核ではあるが Density が 高く出るのか，或は核と全く異つ心顆粒学ているの

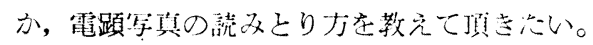

\section{追 加菅沼 惊 (京都府大微生物)}

私共は細菌の形態学的研究の一部として Bradley の Carbon replica technique 公用している。大腸菌 (B 株）について研究した処, 菌の表面に宿没なる部分を愁 河, 現在迄の成絬では之は紐菌の核乃至 Nuclear site に相当する部分ではないかとの考允に到達した。方法と しては菌を篮通寒天にのせたセロフフン上に $37^{\circ} \mathrm{C} て ゙$ 所定 時間培養し直ちにセロファン上の部分を採り出してスラ イド，ガラスに固定し真空蒸着装置に入れる。Carbon 㱏共着した試料は塩酸及び苛性ソータをを使用して寒天並 て゚:二菌体を溶解させ, Carbon 蒸蕒膜を電子頙微鏡で観 祭し心。その結果, 培養直瞧においては囷の中央部に门

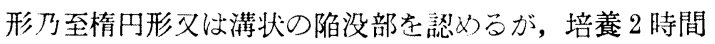
後:こ打いては菌は膨大し両端に 1 対の円形の乼又は 1 本 の維状の陥没を認めるようになる。4〜 6時間後におい て!菌は一般に縮小し, その中央に $1 \sim 2$ 個の円形又は 棈円形の茫を認める。文中には羁が㩊鉿状を呈し，その くでれた部分に一致して Crosswall が認められる場合 もある。尚夫及の時間に招ける菌を Robinow 染色をし て観察した結果, 上記の洋は染色上核と認められる部分 に一致すると思われる。文培養の途中において紫外線を 照射すると菌は細長くなりこの中央に一つて長い紐状の 宿没を認める。以上の結果から大腸菌の表面に見られた 準流 Nuclear site 或いは Bisset のいう Nuclear body

の Matrix を示すものであると考える。
附 倳 菅沼氏心
㕕术 彦吉 (北研)

1）得られた成績は供試菌株 1 株のみによるものか？ 或は普通的なもの亦。

2）供試菌株の生物的及び免疫学的性能はどんなもの か。

回答菅 沼 (京都府医微生物)

1）使用菌株は Escherichia coli（B strain）であり ます。

2）写真で示した様な構造は正常の大腸菌や変形菌等 に一般的な構造と考えいますが，変異型に怙ける場合は 更に検詩する積りであります。

\section{ii 細菌細胞の核裝置及び胞子を中心とした 形態学的研究}

高木 篤（鳥取大細菌）

超薄切片法を応用した電顥的観察により, 数種の菌に ついて, その栄養型並びに胞子の微細構造, 特にその内 部に抢ける核装置の在り方について考察を行つた。

Pseudomonas aeruginosa Cloaca Cloacae にお いては, いずれも Cell wall は薄いが, Nuclear site と Nuclear apparatus に相当するとの内部の索状乃至 網様構造を認めた。特に Cloace の場合の Nuclear apparatus 流等動植物細胞静止核の内部構造を思わせ るものがあり注目された。

Clostridium tetani の栄養型の内部構造も他菌と類似 するが, Cell wall 注厚く明瞭で, Cytoplasmic membrane の存在が確認出来た。胞子形成の過程は俵博士 の報文と同様の所見を得たが，超薄切片での観察によ り, 細胞質の胞子への移入, 胞子の内部構造等につき, 既往の他菌における諸家の報告或いは我々自身の成績と かなり趣を異にするものを見た。菌種による差を考えね ばならない。胞子発芽過程の超薄切片による観察も行 い, 又 Clostridium histolyticum の胞子形成過程が追 求されたが, その模様は多少の相異はあるが, 大体にお いて Cl. tetani の場合瀵似した。

球菌としての Staphylococcus では Cell wal は厚く 明膫で, 中間層を挟んで 2 層構造を示す場合も認めら れ, Cytoplasmic membrane の存在は明膫ではないが その存在を推定せしめる像も得られた。Nuclear site, Nuclear apparatus の存在が涊められた。分裂時の Septa 形成が超薄切片標本で確められた。Streptococcus も Staphylococcus と略同様の所見を示したが, 分裂時には 細胞質の縊切が先行し Cell wall の新生が 随伴する形式が主として認められた。

Pneumococcus は Streptococcus に類似するが，本 
菌に5\%デゾシコール酸ソーダを室温20分間作用さす と, 先ず Nuclear apparatus, 次いで Cytoplasm も溶 解して消失する像を得た事は興味がある。Gonococcus も一般構造は他の球菌と変らないが, Cell wall の極め て薄いのが特徴でこれは一般の Gram 陰性菌の性質々 考えられる。

Candida albicans 及び Saccharomyces cerevisiae を Robinow 変法核染色で観察すると, Feulgen 染色と 同様の像が得られ，円形，棈円形，楔状，三角等の顆粒 が染出せられるが, 細胞分裂に伴つては単純殓切による 分裂像を示す。超薄切片では, Candida albicans では Nuclear site, Nuclear apparatus に匹敵するものを見 るが, Nucleolus 的の構造物を認めた。Cell wall 悄稍 々密度の低い中間層を挟む内外 2 重の膜よりなるが, 芽 生に伴う Bud scar, Birth scar も観察出来る。Chlamydospore の超薄切片像は 厚い壁と内部の中心高密度 部分が特徴的である。

Baker's yeast の切片像は C. albicans と略同様で あつたが，同種又は近縁とも思われた Saccharomyces cerevisiae Hansen No.0021株では膜で囲まれた Nucleus と考元られる部分, 顕著な細胞質内顆粒像 (Mitochondria 等?）が見られ，趣を異にする。Bud scar, Birth scar は認められ. Ascospore は $2 \sim 4$ 室よりな り, 壁は厚く, 各室の中央に高密度の中心部安有する。

\section{追 加望月 成大 (京都府立医大微生物)}

我々は, アノイリナーせ菌, 特に松川, 三沢菌の微細 構造を明らかにする目的で, 超薄切片標本に打ける電子 顕微鏡的観察により, 本菌の核装置の在り方, 及び芽胞 形成の経過につき, 若干の知見を得たので，その一部を 報告する。

超薄切片標本作製方法飞関しては, 固定, 脱水, 包 埋, 切断等型の如くである。但し固定剤オスミウム酸の 働く緩衝液は, 燐酸緩衝液, 及びベロナール緩㣫液(両 者とも $\mathrm{pH}$ 7.4) を併用し，固定時間を 1 時間半から 20 時間迄種々変化させ, 又固定温度も, 水室温等, 条件を 変えて観察を試及た。な打菌の培地はすべて, 普通寒天

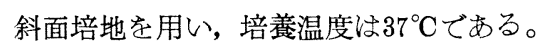

観察結果の内容について, 総括すれば, 栄養型に扢い ては, 外側より, 細胞壁 cell wall 細胞質 cytoplasm, 細胞質中の空胞 Vacuole, 空胞中に見られる Nuclear apparatus 等が識別され, 細胞質膜 cytoplasmic membrane については確認する事が出来なかつた。 nuclear apparatus 2 本の thread が螺旋状にコイル状に巻 きついて形成されて居り, paired chromosome like nucleus 上考えられ， active nucleusのーー上考えられ る。

栄養型の terminal subterminal につにられる溯苏泡 は, 次第に完全芽胞】と進んで行くが, 二の経過の途 中で，芽胞の中央汇在る円形の nuclear site 取囲え で種从の方向に突起を持つ electron dense な物質む゙出 現し, 此の物が, この内部に而に density の高い突起 の軸と思われるもの在秘わている。更に完全芽胞になる とか〉る突起は 5 方向に制約されてくる。本菌のSpore coatは，2層から成ると思われ， spore の核装置は中

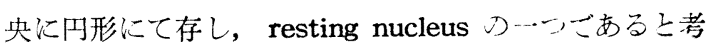
えられる。

追 加吉井 善作 (山口医大微生物)

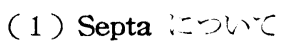

a) Borrelia duttonii 深㧈いても細胞体軸汇求心状 に cell wall の濃密化が行われ, Ring が形成される。

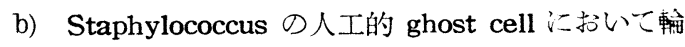
状の cell wall の濃密環と元の部分に扎放断裂遊踓方 認められた。この環には大小区从のものがあるが，分裂 の進行に伴つて, Ring が縮少して行き,完全なる septa の形成完了与共に分裂が完成するのではないかと考え る。

（c）との Staphylococcus の場合 Ring は第 1 次形 成進行中, 娘細胞に打いて第 2 次の Ring が第 1 次の今 のに直角に形成され始めている像がある。之の様式がブ ドウ状立体的配列をとる基礎となつている。

2）原形質膜について

a) 桿菌，螺旋菌ではよく発達しているようである。

b) ブドウ球菌，淋菌にも原形質膜と見做される像す よくみられる。

3. 山口医大皮フ科教室の馬込氏は淋菌の菌体内顆粒 を同定するために核酸の定星法を用いて考察を加えてい る。淋菌は陳旧培養によつて。自家融解し ghost 化し て行くが RNA は激減しているが DNA は減量しない と。

か〉る方法は或程度の参考となると思われる。

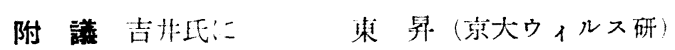

原形質膜が認められるとの折ですがーとの写真には原形

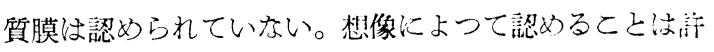
されない。

追 加公野 耀雄 (京都府医大微生物)

炭㾇菌の成熟型の超薄切片像では, Nuclear element $の$ fibrous structure $\varepsilon$ cytoplasm $の$ dense な granules との速絡しているのが観祭され, Cell wall の阶 
江 less dense な portion が求心性に向つているのがみ うれ, 更に cross plate が半济求心性に形成され, 娘細 胞が Connecting string で連結され, mitotic figure に 似た像が観察された。

芽胞形成では Vacuole like-inclusion body がみら れ, 一方に dense portion があり,こ〉に forespore が 形成され, spore coots が形成される。 spore coots 殊 : outer coots は cytoplasm の中に带状に形成され, cytoplasm が spore 内に condensation されるのが観 祭された。尚 inner coats は二車の膜から形成されて いるのが観察された。

炭疽菌特有のCapsuleについては, マウスの肝細胞内 の炭疽菌について超薄切片法を適用した。オスミック酸 の固定時間が短い場合には炭㾞菌細胞の周囲に dense な slime が観祭されるが炭瘨菌細胞の Nuclear site 十分観祭しうる程度にオスミック酸固定を長くすると, cell wall $に$ dense granules が附着し, fibrous structure，透明部の三層が同心円的に観察された。

附 高不氏に 野 (京都府医大微生物)

B. anthracis $の$ vegetative form $k$ mitotic figure に似た像がみられた。 spore 形成については vacuole like inclusion body がみられ, sporeは cytoplasm の Condensation によつて形成されるととが分つた。

マウスの肝細胞内の B. anthracis の Capsuls はオス ミック酸の㭙間により granular 層, fibrous 層, 透明 層がタられた。

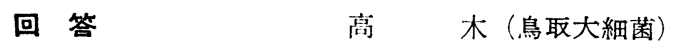

五方向に突起を出している芽胞膜の高密度部分は芽胞 膜に虽するものではないかと考える。茅胞膜外細胞質の 濃縮像とすれ以゙, 発芽の際と, 本来の苐胞膜より離れて 離脱して行く事が見られるのではないかと考えるので其 の点を確められては如何ですか。

\section{iii 細菌細胞膜及び芽胞膜を中心とした 細菌解剖学}

\section{吉羽屡,（徳島大細菌）}

真性細菌の形態学的特厓の一つは細胞膜 (C. W.) の

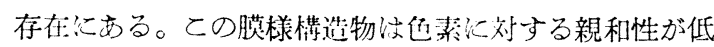
々，分離も困難であつたので，卧い間研究の対照から 除外さられていたが，近年に至つて Bisset, Knaysi, Salton, 吉四等の研究によつてようけ々，次存在と機 能が注目せられるに至つた。

今回私共は C.W. と芽胞膜（Sp.m.）を中心とした細
菌解剖学について研究の一端を報告する。

1. C.W. 染色 : O.C.法, O.J.法, P.V.法, P.A.法, P.C.C. 法; Victoria blue 法等 6 種類の染色法を考案 してこれらの染色法が従来の染色法に優るということを 証明した。

2. C.W.の分離法：私共は独自の構想で $\mathrm{T}-1$ 型及 び $\mathrm{T}-2$ 型の細胞膜分離装置を考案し, あらゆる細菌か ら C.W. が分離出来るとと学証明した。

3. 分離 C. W. の電顕的観察 : Salm. typhi, V. cholerae, Brucella melitensis, B. subtilis, B. cereus 等の C.W. の E.M. 像走示し, 更に B. subtilis やB. cereus の Endospore membrane が 分離出来るととや Endospore に支持装置が存在するとと在も証明した。 またトリA62株の C.W., Cytoplasmic membrane(C. M.) を初めて示し, Proteus vulgaris の granule む゙ 純粋にとり出せるという可能性について論じ, Granule membrane (G.M.) の E.M. 像を示した。

4. 細胞膜を中心とした微細構造

Staph. aureus $の$ macromolecules, B. subtilis C. W.の内外層, B. subtilis の Crosswallring, Krebsiella pneumoniae type A C.W. $\odot$ filament, Tricophyton interdigitale C.W. から出ている螺線状突起物, また同 菌の budding 像と超薄切片による C.W. の二重構造と ミトコンドリア，並びにグラム陰性菌に出現する disc body 等についてそのおの㧍のの 形態学的特長について のベた。

5. 細胞膜, 芽胞膜の化学的組成： E. coli B. 菌の 変異菌12株並びに B. cereus の C.W. と Endospore membrane の化学的組成の差異を論じ, かなりの差異 があるというととを証明し得た。またグラム陽性菌扢よ び陰性菌 C.W. の紫外線吸収を測定して, C.W. にあら われる hump の種類には 4 つり, その内 $270 \sim 290$ $\mathrm{m} \mu$ にわたる hump は両性菌に共通的なむので陰性菌 に特長的なものでないというととを示した。

6. 細胞膜と原形質膜について E. coli B. C.W. 在 Lysozyme やE D T A 等を使用して溶解濁度を測定する と共に Lysozyme による M. lysodeikticus の溶菌過 程老光䫓的並びに流動吸光的に示し, その C. W. 及び C.M. の分離法を確立し, 化学的仙両者爷分析比較する 上共に本菌の黄色色素が C.M. に由来しているというこ とを示した。

7. 細胞膜に対する Bacteriophage の吸着 : E. coli B. の C. W. を無菌的に分離し, $\mathrm{T}_{4}, \mathrm{~T}_{5}$ phage を吸着 さしてその吸着像を E.M. 像で示し, C.W.を化学的に 
処理して $T_{4}$ phage の吸着実験を行い, receptor substance の活性因子が多糖類分劃に存在しているという ととを示した。

8. コレラ菌の抗血清による溶菌膜現象：抗血清によ る溶菌現象は, 抗 C.W. 血清による C.W. の溶解によ つて惹起せられるものであるというとと老 E. M. 的に 証明した。

9. C.W. に対する重金属イオンの吸着能： E. coli B., V. cholerae, B. subtilis, B. megatherium 等の C.W. $\mathrm{CuSO}_{4}, \mathrm{FeCl}_{3}$ 等の水溶液に浸け, ポーラログ ラフを使用して C.W. $1 \mathrm{mg}$ 当りの吸着量 (mg) を測 定した結果 $\mathrm{Cu}$ よりも $\mathrm{Fe}$ の吸着が大であるということ 学知つた。

10. 細菌細胞の流動吸光的研究: 細菌性条光の原理々 その測定理論を述心゙, 私共の考案したベックマンアタッ チメントの装置並びにそれによる各種細菌の測定值を示 し, 細菌の短経長経比が重要な因子であるというととを 強調した。更にその応用面の一つとして, Phage の吸 着と増殖の状態がこの現象側から推定できるということ を報告した。

\section{附議中野彌（東京医細菌）}

Cell wall が filament 状に出る条件が一定している かについて。

回 答 吉田(徳島大細菌)

C.W. の macromolecules が filamentous arrangement をつくるのには $1 \mathrm{~N} \mathrm{HCl}, 100^{\circ} \mathrm{C}$ 加熱法がよい ようです。Aq. d. で煮沸しても出来ます。苛性ソーダ で乽沸するとあまり filamentous arrangement をつく ること訬ない。

\section{附 識矢部 芳郎 (岡大微生物)}

私がブドウ球菌において分離した顆粒分劃は各菌種特 有の色をもつて拀り，終未呼吸素に関与した酵素活性 をもつている。先生が示された B. megatherium の Cytoplasmic membrane suspension は菌特有の着色を しているとの事であるが, 呼吸酵素活性はしらべられま したか。

又 Weibel は B. megatherium Cytoplasmic membrane は呼吸に関与した顆粒を附着している。といつて いるが, この Cytoplasmic Membrane suspension の 着色は, その Membrane と顆粒の何れにあると思われ ますか。

\section{回 答}

吉田（德島大細菌）

純粋にした, C.W. と Cytoplasmic membrane の浮 遊液をつくつたととろ, 菌のもつ色素が C.M. suspen-

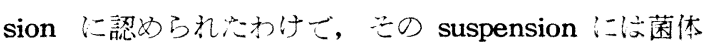
内顆粒は含んで抄り志ん。
追 加
吉 井（山口医大微生物）

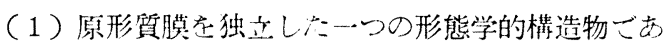
るょの考えについては，秒の多くの観然例からしてむ犬

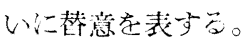

(2) Cell wall : :文球状粒子が配列している層がる ることは私もある種の細菻で涊さている。例アアノリ ナーゼ菌（木村，门山落）

\section{回 答}

C.W. の macromolecules ${ }_{\alpha}$ Hexagonal patern.

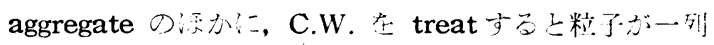
にならび, filamentous arrangement 在ここことが心

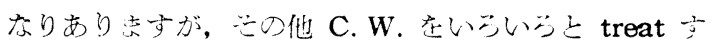

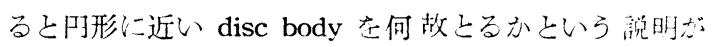
つかなくて困つていミす。

\section{诈 問 渡辺義一!北研}

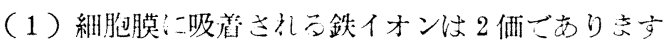

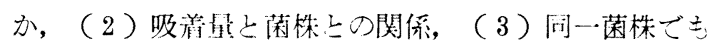

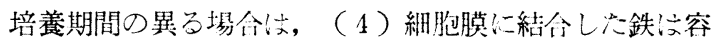
易过遊離し得るものか心ついたデータが沶ありになつた ら御教示いたざければ悻い゙す。私達はジフテリア毒素 産生条件を检吋中ジ菌が多直の鉄を吸着することに気が ついて抢りますので，堙地中!二一定勾に加入された鉄が

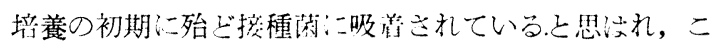

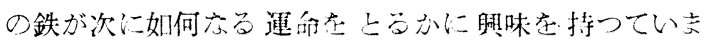
于。
回 答
吉田（德岛大細菌）

(1) C.W. $1 \mathrm{mg} の \mathrm{FeCl}_{3}$ 吸収帒 $(\mathrm{mg})$ をしらべると E. coli B. $(10.6 \mathrm{mg}), \mathrm{V}$. cholerae, $(5.6 \mathrm{mg})$ B. subtilis, (10.0 mg) B. meg. (6.9 mg) CuSO, 江,

$2.5 \mathrm{mg}, \quad 5.7 \mathrm{mg}, \quad 2.7 \mathrm{mg}, 4.1 \mathrm{mg}$ であり, 菌に よつてちがうようでな。

若い菌の C.W. と老化しネ菌の C.W. 汇ついてい本

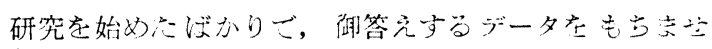
ん。本奏験では17〜20㭙間培盖のもの在用いた。

(2) Feイオンは 3 価だけを朋いた。

$\mathrm{FeCl}_{3}\left(10^{-3} \mathrm{~mol}\right.$ 蒸溜水液) に15〜 40mgの乾嚳 C.W. 定一夜つけて招き, 上澄の $\mathrm{Fe}$ の減少をしらバた。

\section{vi 枯草菌芽胞の発芽における 形態の変化と 代謝について}

蜂須賀養悦（名大細菌）

枯草菌（P C I 219）芽胞の発芽率を知るた故光霓式 
比色計を用いる方法を案出した。この方法を用いて発芽 に㧍汀る栄養要求, 特仪窒素源, 炭素源との関係を研究 し，更には発芽に扔ける呼吸醳素系の発生などについて も述べた。

（1）枯草菌芽胞は燐酸䌅衝液に L-asparagine,

DL-serine, DL-isoleucine, DL-valine 等を各単独に加 へることよつて発芽が著しく促進されるが，との時カラ メルが必要である。

（2）発芽及び栄養型の增殖汇対する作用から窒素源 を四つのグループに別けるととが出来る。即ち（イ）両 者に対して無影響なもの（口）発芽にの及有効なもの （八）增殖にの及有効なもの，（二）両者に有効なもの でする。DL-isolencine は（き）に属しているに拘ら ఘ゙ L-isolencine は (イ）嘱す。

(3) 芽胞は (イ）透明部分の出現，（口）出芽口の 形成，（八）新生細菌の出現，（）新生細菌の栄養型 への進展の四つの段階を経て発芽を完了するが，同じく 発芽にのみ促進的に働くアミノ酸でもその種類によつて 作用が異る。DL-serine では（口）の段階まで，他の三 種つアミノ酸は（ハ）の段階まで進展せしめる。このこ と注各発芽段階の栄養要求の異るととを示している。

(4) 発芽にの及好的に作用する DL-serine が增殖 にの及促進的沪作用する L-glutamic acid の作用を阻止 する。両者を最初から合成培地飞等量内至 DL-serine を L-glutamic acid より高濃度に加へた場合, 発芽は DL-serine 単独の苆合と同じく行はれるが菌膜形成は 阻止される。この DL-serine の作用々 DL-tryptophan にょつて堌殖される。L-histidine に対しても DL-serine, DL-tryptophane は同じ作用を示す。

（5）発芽を促進するのは無処置のブドウ糖でなく， ブドウ桾のカラメルであるブドウ糖以外に果糖, バクガ 糖, 蔗糖, 乳糖のカラメルも発芽促進作用がある。その 際, 発芽を促進するアミノ酸の共存が必要である。

(6) 酲酥及びT C Aサイクル上の中間代謝物はカラ メルに代り得ない。

（7）カラメル，アスパラギン培地に沶いて，各種醉 素阻害剤は発芽の第二段階までを阻止する作用がない。 それ以後の発芽段階はある種の阻害剤によつて阻止され るがその作用にも差異が見られる。

（8）透明芽胞はブドウ糖及びグルコン酸を酸化しう るが, 醴醅及びT C Aサイクル上の中間代謝物は酸化し 得ない。

（9）ブイヨン及び合成培地中で培養された芽胞は培 養時間の経過とともにピルビン酸, コハク酸を酸化しろ
るに至るが，ブイヨン中で培養されたものは合成培地中 のそれに比して早期にてれらの酸化能を持つて来る。

(10) ブイヨン中で発芽した発芽芽胞中発芽培養時間 が 4 時間以下のものによるブドウ糖酸化はモノヨード醉 酸によつて促進されるに拘らず, 合成培地中で発芽した 発芽芽胞は発芽培養時間に関係なく著明に阻害をらけ る。とのととは両者のグルコース酸化䤃素系に差異のあ るととを示す。

（11）芽胞は芽胞の進展に伴い徐々に, 栄盖型の持つ ている好気性菌特有の呼吸酵素系を獲得して行くものと 思はれる。

闑吉 井 (山口医大微生物)

各種の芽胞菌の芽胞について比較なさいましたか？

回 答

蜂須賀養悦 (名大細菌)

枯草菌 P C I 219 株の芽胞についての及実験してお り, 他の芽胞についての成績と比較出来ません。しかし Hills, Powell, Halvorson 達は枯草菌芽胞の発芽につい ての研究で, adenosine や alanine が発芽苦著しく促 進すると述べていますが私は之等 2 つの発芽促進作用は 認めませんでした。この様に同じ枯草菌でも strain に よつて発芽要求はかなり違うのではないかと思います。 但し発芽を云从をする場合注意しなくてはならないのは 発芽の基準を何に置くかと云うことで御座います。即ち 発芽は四つの段階を経て完了致しますから, 発芽の基準 の取り方ではちがつた段階を基準にして発育を問題にし ていることになります。従つててれら発芽に関する研究 は発芽の基準を同一のものに抬いて再検討したいと思い ます。

\section{v 細菌の顆粒に関する研究一一主として抗 酸性菌について}

武谷健二 (九大細菌)

電䫓によつて抗酸性菌を観察すると大別して 3 種の顆 粒が見られる。すなわち; density の大きい大顆粒と小 顆粒及び空胞様顆粒でこれらを便宜上 A， B， C 顆粒と 呼ぶ。Knaysi がこの A 顆粒を核であると発表して以 来, この顆粒の本態が論争のまととなつて扣り， Mudd のミトコンドリア説, Ruska, Bringmann, らの Karyoidあるいは Nucleoid 説, Werner の Volutin 説な ぞがある。との問題に関して, 1953年電顕学会シンポシ ウムに抬いて, 一応の成績を発表したが, その後共同研 究者らとともに行つた成績を主としてのべる。

1953年の報告は同一菌の光顕像と電顕像とを対応させ 
る方法と主として，A 顆粒の本態が核でもミトコンドリ アであなく，代謝に関係媣い物質一メタフォスフェイ ト一の集積したものであらうとの成績であつたが，その 後の諸家の成績もほぶこれと一致し, 現在のとてろ核で はなく、メタフォスフェイトを主成分として含むという 結論が得られている。

ミトコンドリアとの異同については,その後 Brieger, 篠原らも同一菌対応法によりわれわれの成績を確認した が，一方 Mudd との共同実験を行つた結果，菌の発育 時期, 培地組成等によるメタフオスフエイト顆粒とミ卜 コンドリアとの消長の比較実験や，テルル酸カリ還元顆 粒の同一菌対応法などによつて，両者は別個の顆粒であ るととをさらに確め得た。しかし, メタフオスフェイト 顆粒の形成にミトコドリアが密接を関係をもつととは充 分考え得る。 $\mathrm{B}$ 顆粒も種々の理由から $\mathrm{A}$ 顆粒と同様の組 成をもつと考えられる。

凍結融解により菌体からA顆粒の分離に成功したが, 尚その量が充分でないので化学的組成を正確に検討する には到らなかつた。

菌体内に見られるこのメタフオスフェイトは高エネル ギーのプールと考えられ，（A T P ₹A D P + Metaphosphate）なる反応が醳母で見出されている。との顆 粒はCorynebacterium, Mycobacterium, カビ, 醅母で は正常状態で見られるが，てのようなメタフオスフェイ 卜形成はこれらの菌に限らず, 他の細菌, 例えば Acrobacter, S. paratyphi B なぞであ特殊な条件下では顆 粒として認为られることを明ら玑した。恐らくこれら の菌では正常状態では形成されたメタフオスフェイトは 顆粒として蓄積されるのをまたずェネルギー源として使 用されるものであらう。

形態を機能と関聠させて 研究するといろ意味で, “ resting cell” に各種の基質を与えてメタフォスフェ イトの蓄積を見るという方法で種々の実験を行つた。と の反応は 2，4 DNP及び Azide で阻害される。 SM もこれを阻害するが，SM耐性菌ではこの阻害が起らな いととは, 別の立場から行われた田中らの生化学的研究 の結果とよく一致する。

細菌のミトコンドリアの問題は, 篠原が超薄切片によ つててれにきわめて類似した構造をとらえているが，て の方向の形態学的研究と, 醭素活性をもつ顆粒劃分の分 離に関する山村一脈, Youmans らの生化学的研究とを 平行協力させて進めることによつて解明されるものと信 ずる。

\section{附山中 太木 (大阪医大微生物)}

(1) 命名の点で $\mathrm{P}$ 顆粒は Metaphosphate, phosphorylation の意味と pol に在ると云う 解剖学的劣意困 て, L顆粒註 Lipochondrialike でM顆粒は中間位に在 り，多分に Mitochondriol との推定に立つた形々機能 の面の統一的な Hypothesis を立てた上での命名です。 将来統一される時期に至れば固執するものてはない。

併し A， B， C 命名は平面的で私共は物足なかつた し, 機能を加味した新しい根拠に従つて斯く多少立体的 だと思う命名をしたものである。

(2)「ツ」産生との関連は従来の個々別々の結果論的 観察と別に経時的な追及から一定の関係のあるととを認 めている。

\section{追 加篗原 近知 (東北大抗酸研)}

(1) Ziehl-Neelsen 染色を施した結核茵を光学顕微 鏡で撮影した後，電子䫓微鏡で撮影対比し，結核菌本来 の顆粒は Ziehl-Neelsen 染色過程心消失することを知 つた。との現象は主として媒染凩である5\%の石炭酸に 由来することを知つた。従つて Ziehl-Neelson 染色菌 に見られる顆粒様構造は本来の構造とは異つたものて ある。Fontes 染色に执いても同様である。

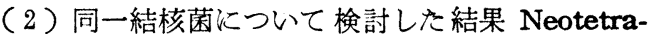
zolium 還元部位と電子線顆粒とは必ずしも一致しない ととを知つた。又鳥型菌の超薄切片像に扮いて電子線顆 粒 (本来の顆粒) の他にミトコンドリア様構造を認め た。

（3）鳥型菌に種及の核酸除去法を行つてその処理液 を分析すると共に，被処理菌の超薄切片を観察した 結 果, 超薄切片に扮ける空胞様構造の中に見られる紐状構 造は，RNase を作用させた場合には醉素活性を示した 汇も拘らず残存したが， RNase 作用後 $5 \%$ \%リクロー ル酢酸作用を行つた場合には完全に消失し，同時にこの 抽出液にの及紫外線吸収と共に diphenylamine 反応陽 性を示したととから，本構造の主成分はDNAであると 考えられる。

(4) $\mathrm{N}-\mathrm{CH}_{3} \mathrm{COOH}$ を用い電子線顆粒を特異的に抽 出し次の結果を得た。紫外線吸収, Orcinol 反応, $\mathrm{P}$ (燐 モリブデン酸アンモン法), Molisch 反応, N(Lassaigne 法）が陽性, diphenylamine, Fehling, 坂口, Biuret反 忘恃陰性であつた。

追 加 篠 原（東北大）

1）Ziehl-Neelsen 染色過程に電子線顆粒は消失す る。

2）鳥型菌の超薄切片像に扣いてミトコンドリア様構 造を見た。 
3）鳥型菌を種々の核酸抽出法を行つてその処理液の 分析を行了と共に被処理菌の超薄切片像を観察し, 空胞 碌構造の中の紐状構造の主成分はD N Aであることを確 認した。

4） $\mathrm{N}-\mathrm{CH}_{3} \mathrm{COOH}$ で電子線顆粒を選択的に抽出しそ の組成をしらべた。

\section{回 答}

武 谷 (九大細菌)

1. 切片中のミトコンドリアの問題は講演中でのべた から省略する。たぶカビ，醅母までに見られていたミト コンドリアが次のミコバクテリウムにも見出されたとい ろとと结興味染い。

2. $\mathrm{Z}-\mathrm{N}$ 顆粒, Much 顆粒はA 顆粒より多数に見ら れ人工産物を含むことは数年前に報告したが, 御追加は てれと一致している。

3. A 顆粒の 抽出液の化学的性質を 調べていられる が，乙の抽出法では顆粒のみならず，菌体成分をも抽出 してる可能性があるから，われわれの行つているょうに 顆粒を分離，精製されるべきであらう。

附 東昇

確実にミトコンドリアであるという点について。

鳥型結核菌の超薄切片に見られる「ミトコンドリア

樣」といわれるものは肝, 脾, 等のミトニンドリアと全 く同一の獚造（膜拧よびクリスター等）を呈するから形 態学的に之をミトコンドリアと認めるととができる。

\section{追 加 土 屋 (福島衛研)}

N T C 還元顆粒の観察方法について私共法予め培地に NT Cを添加しておいたものに半切ガラススライドに材 料を塗抹し插入し $37^{\circ} \mathrm{C}$ に一定期日培養後，それをとり出 し固定しこのま 鏡検すると定型的な顆粒状呈色所見と してみられる他に細長の桿状に醳素活性の強い部をも認 めているので還元顆粒と称するょりは N T C 還元部位乃 至は還元物質とでも呼ぶ方が適当なものではないかと考 える。

\section{回答武 谷 (九大細菌)}

Tetrazolium 還元顆粒は長く色素と接触させれば当 然大きくなり，数個のものが融合する。この融合した像 を見ていられると思う。しかし，ての䤃素活性は顆粒状 の部分だけでなく，一部は菌体内にも散在しているょう である。

追加中井益代 (大阪医大微生物)

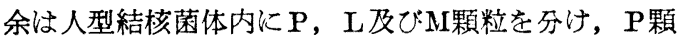
粒の出現に $\mathrm{Mg}^{++}$が影響する事から燐酸代謝に関連する あのと推定し, 及 Phosphate を多量に有するものであ ると考える。又同一時期に抬ける Substrate の交换をや
つた所見や、ツベルクリン産生並にアミノ酸代謝と顆粒 出現を検討した成績からしても一定の代謝䞟路に従つて $\mathrm{P}$ 顆粒が変動する事は問違ない。尚潘グリセリン濃度を 増加した場合顆粒が増大し，特に $6 \%$ ではラセン状の菌 が現われた。さらに超音波や凍結融解法によりて菌体を 破壊し, Spinco 超遠心機によつてP顆粒を分離し，そ の電子線畐折像によりて菌体と明办に異つた 趈折像を 示し，併せて Feulgen, Robinow 染色による結果を述 べた。

以上の事から結核菌体内の $\mathrm{P}(\mathrm{L}$ 及びM) 顆粒夫く生活 環境に応じて刻々変化を来たす所謂代謝性顆粒（Metabolic adaptic granules） と考えるが，之と別に粘膜 から分離した一桿菌が連接した細胞に执いて規則正しく 対称性に出現する事から構造性顆粒 (Structural genetic granules）と見られる点を述べた。

追 加 中 井 (大阪大微生物)

(1)人型結核菌においてP， L，M顆粒を見出し，同 一時期に medium の Substrate を変化した場合の顆 粒の変化を示し，代謝性の顆粒である事を述べた。

（2）粘膜から分離した一桿菌が連接する場合に顆粒が 対称的に並んで居る此の様な場合は構造性顆粒と考えら る。

(3) P 顆粒を分離してその物理性状について述べた。

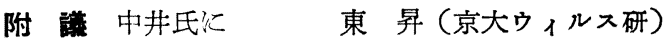

P顆粒の電子趈折のパターンを示されたが，それは廻、 折パターンになつていない。パターンであれば如何なる 形のパターンであつても輝度最大の電子スポットを中心 にして現れなければならない。

\section{回 答 \\ 武 谷（九大細菌）}

1. 顆粒の命名について, われわれは最初に命名した Knaysi にならつて，A， C 顆粒とよび, 更に別種の顆 粒が見られるのを B となずけた。後から研究をはじめる 方は前の命名を尊重された方が混乱を少くするのではな いか。

2. A 顆粒とツベルクリン産生とを関係づけられるの は大変危険と考えられる。

3. A 顆粒が代謝に関係深いとと，及びA顆粒を分育 精製されたととはわれわれの成績を追試確認していたぶ いたものと考え感謝する。

追 加楠 瀬 (大阪刀根山結核研) われわれは鳥型菌はじめ多くの抗酸性菌の菌体から分 画遠心沈溉法によつて Particulate fraction を分離し た。このfractionは電子䫓微鏡写真によると径 $50 \sim 150$ $\mathrm{m} \mu$ を有する顆粒から成り, ヤーヌス緑に好染性, 燐脂 
質扣よび燐蛋白に富み，PNA. 含量の D N A に対する 比は大きい。またLーリンコ酸, コハク酸，DPNHお よびT P NH各脱水素醳素, およびチトクローム（ $a_{1}$ $\left.b_{1} c_{1}\right)$ がいづれも特異的にての部分に濃縮して存在し ている。すなわちこの fraction は機能的に動植物細胞 のミトコンドリアに類似すると考えられる。この様な生 化学的研究と形態学上の知見と如何に関連するか御教示 願いたい。

\section{附㦈 楠瀬氏に 矢部 芳郎（岡大）}

私がブドウ球菌に 40,000 r.p.m. 遠沈を行つて得た 顆粒分劃と, 可溶性分劃に捛いて, 乳酸々化活性はこの 両分劃の間で完全に分かたれるが,リンゴ酸々化活性は, 充分明らかにはこれら両分劃の間に分かたれない, 従つ て顆粒にも種々あつて, 各及呼吸に関する役割が異つて 居ると思われる，これに関して結核菌の場合と比較して 御考察をうけたまわりたい。

40,000 r. p. m. 遠心の上清に残る顆粒と, 沈渣とし て得られる顆粒とは同じものと考えられますか。

附袓 楠瀬氏に東昇

醭素活性粒子の大いさの問題は, その粒子含有液を鏡 検か 支持膜上で空中乾燥させるときの表面張力の影響 で粒子の大きさは大幅に変動するととに留意すべきであ る。

この変動を除くには三次元法が最もよい。これができ ないときは次善の方法として噴霧法によればょい。それ によつて大きさの問題に対する心配は除去できる。すつ とも，粒子フラクションがもともと本質的に異つてい るのだとすれば問題はその方面を検討しなければならな い。

\section{回答 楠瀬氏に 武 谷}

Youmans のEM像は劃分必ずしも均一な粒子からな つていないし, 醳素活性もかなり小さい粒子から大きい 粒子にわたつているょうて， これには座長の指摘した試 料作製の問題も関係していると同時に, 顆粒自身がかな り labile なものであることを思わせる。
今後, 前述のように形態学と生化学との研究者が協力 して研究を進めることがこの問題の解決には必要であ る。

回 答武 谷(九大細菌)

生化学的な研究方法については濃度の中でのべたのて 別にのべない。今後われわれの形態学的研究と貴方達の 研究とを関聠させるべく努力したい。もし破壊方法と分 離顆粒の大きさ，酻素活性との関係を調べていられるな ら示していたざきたい。

\section{回 答楠瀬 正道 (大阪刀根山結研)}

われわれと Youmans 等の particle の大さの差に関 しては, particle はかなり labile な構造を有し, 菌体 外に分離された場合，条件の相違によつて著しくその大 さ等に影響をうけるものと推定される。また particle の aggregation 等も抢てつてょい大きい particle の生 成も予想される。

\section{〔総括】}

東界

核, ミトコンドリア, 細胞膜, 胞子等を中心に, 光学 顕微鏡的, 細胞化学的, 電顕的に研究した成績について 討議した。細菌細胞における核の明確なる存在および核 質の構造特に螺旋染色糸の存在がかなり明らかにされた といつてよい。次に Trychophyton および鳥型結核菌 に超薄切片法と電顕とによつてミトコンドリアを形態学 的に同定できた。それまで単に顆粒とされていたものの ひとつにミトコンドリアが合まれているととが明らかに なつた。一方生化学的にも(鳥型結核菌) ミトコンドリ アのフラクションが得られたとと等は特筆に值する。細 胞膜は種によつて形態を異にし, 叉化学的成分を異にす る場合もあるととが明らかにされ, 胞子発芽に必要なエ ネルギー源抢よび発芽の形態学的様式等が述べられた。

今回の形態学は所謂一般形態学にとどまり分子のレ心゙ ルで構造を究める分子形態学にまでふれなかつたが, 近 き将来に必ず本邦に打けるこの方面の研究も分子形態学 に足を踏み入れることにならう。 